\title{
CYCLIC LOADING TESTS ON STEEL PORTAL FRAME KNEE JOINTS
}

\author{
M. J. Beamish ${ }^{(1)}$ \\ Presented at the Pacific Structural Steel Conference, Auckland, August 1986
}

\section{SYNOPSIS}

The results of cyclic loading tests on three full-size portal frame knee joints are presented. All members complied with the flange and web slenderness limits for plastic design (AS 1250-1981) but were the lightest sections for their respective depths. Large decreases in load capacity were observed when either lateral-torsional or combined local flange and web buckling occurred. Lateral restraint forces were measured and were found to exceed the minimum ultimate strength values specified by the design code rules. One fully welded connection and two bolted connections were used and suffered only minor damage during the tests.

\section{INTRODUCTION}

Many researchers have considered the design of steel portal frames for static loading by either elastic or plastic design methods, but few have studied their behaviour under high intensity seismic loading. Due to their low mass and height, the design of the majority of portal frame structures is governed by non-seismic load cases such as gravity, wind and crane loads. In such cases the significance of seismic loads may be assessed by assuming a seismic coefficient appropriate for elastic response. This would give an indication of the level of ductility required if the structure is to survive a major earthquake of the intensity implied by the design code. If this approach shows a significant ductility demand then the use of elastic design methods must be questioned. If the ductility demand is high a fully plastic collapse mechanism can be expected to form and the frame should be detailed accordingly using capacity design procedures.

A review of previous test results by several researchers (Beamish 1984) found that local and lateral inelastic stability problems in steel members become more severe if the load is applied cyclically rather than monotonically. Popov (1973) found although local buckling occurred in members satisfying plastic design flange slenderness limits no immediate drop in load capacity was observed. He suggested that more conservative flange and web slenderness limits may be needed for cyclic loading and that the compression flanges should always be braced to prevent lateral-torsional buckling. Whittaker and Walpole (1982) and Matsui and Yoshizumi (1980) found that web buckling following the flange buckling lead to rapid decreases in load capacity. Vann et al. (1973) concluded that beams with flange, web and minor axis slenderness ratios close to the plastic design limits may exhibit unstable hysteresis loops but

(1) Graduate Student, Civil Engineering Dept., University of Auckland. deterioration would be severe only when local flange buckling combined with either web buckling or lateral-torsional buckling.

For economy, a typical portal frame will often have the lightest members in a particular size range so it is important to consider the effect of cyclic loading in view of the previous test results. In this paper the results of three tests on full-size portal frame knee joints are presented. The aim of these tests was to evaluate the performance of three different joint configurations and to investigate potential stability problems.

Morris (1981) has reviewed the design of portal frames by both elastic and plastic methods but the only joint type considered was a bolted, haunched joint detailed for a closing joint moment. The most common joint detail used in New Zealand is a fully welded connection with a diagonal stiffener. This detail, along with a bolted end plate joint and $a$ haunched joint with a bolted end plate were tested. The bolted end plate details axe similar to those tested by Johnstone and Walpole (1981), Whittaker and Walpole (1982) and Plugge and Walpole (1983).

\section{TEST SPECIMENS}

The 'model' structure used to select the dimensions of the test specimens was a single bay portal frame with a span of 25$30 \mathrm{~m}$, an eaves height of $6 \mathrm{~m}$, a roof pitch of 1 in 5 and partially fixed bases. The chosen leg length of the test specimens $(4 \mathrm{~m})$ approximates the points of inflection for gravity loading. The member sizes were selected using a plastic design with the requirement that the sections should be the lightest in their size range so that any problems with local buckling could be investigated. Capacity design procedures were used when designing the bolted connections.

Specimen one (Figs. 1,4) is a typical fully welded knee joint with a diagonal stiffener. Although the lateral restraint 

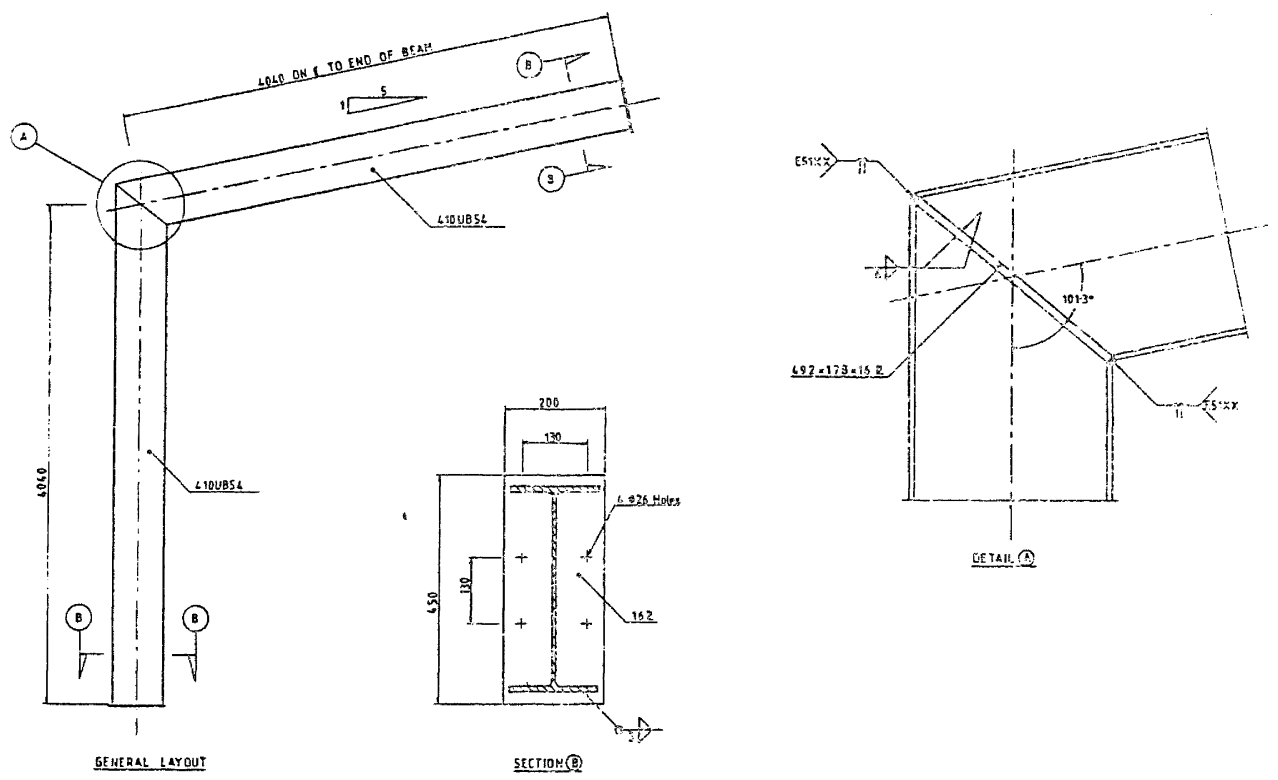

FIG. 1 - SPECIMEN DNE DETAILS

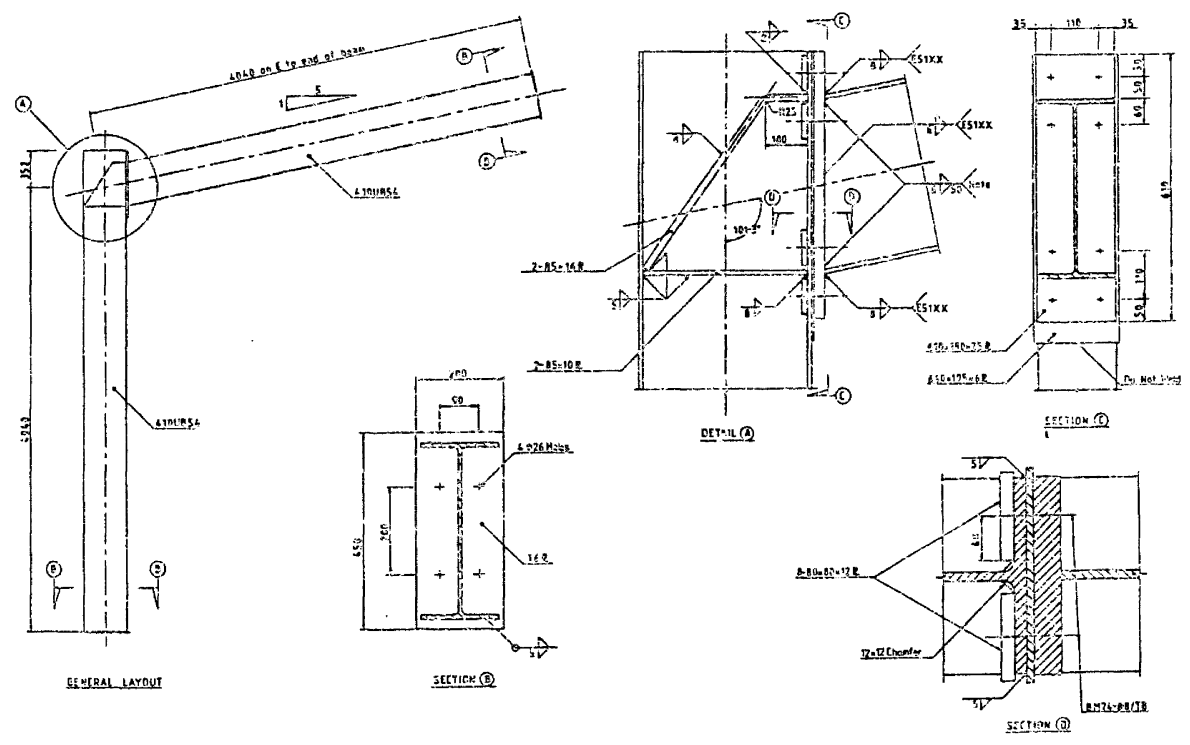

FIG. 2 - SPECIMFN TWO DETAILS

spacing satisfied the rules for plastic desigin in AS 1250-1981, the expected fajlure mode was laceral-torsional buckling.

Specimen two (Eigs. 2,5) used a bolted end-plate connection wjth a diagonal seiffener configuration developed by Morris (1.981). A thin plate was welded to the outside of the column flange to replace the area lost at the bolt holes and to stiffen the Elenge argainst deformation caused by the bolt tension forces. The 12 $\mathrm{mm}$ backing plates piovide extra columi flange strength - icetemejer (1981) has suggested that a $50 \%$ increase in strength can be obtained using plates slightly thicker than the columi flange. The bean plastio moment was increased by $25 \%$ for the connect- 
ion design. The end plate thickness is between the values obtained from the surtees and Mann (1970) and the Mann and Morris (1979) formulas. The bolts were sized by assuming that the flange force is shared equally by the four bolts and that the prying forces are allowed for by using the proof load rather than the ultimate lood. The column flange strength was calculated using a yield-line mechanism suggested by Packer and Morris (1977).

Specimen three (Figs, 3,6) was a haunched joint where the haunch was formed by a triangular off-cut from the beam section. The bolted connection was designed using the same method as for specimen two but was slightiy under-designed (allowing for a 25\% over-strength beam). The end plate size was obtainea from the Surtees and Mann equation. The laterai restraints were positioned around the possible plastic hinge Iccations to prevent lateral-torsional buckling. Restraint No. 5 (Fig. 6) was moved during the test to the indicated position when lateral deformations were observed in the vicinity of the top flange connection.

\section{TEST PROCEDURE}

The layouts of the test rig and the laterai-restraint positions for each specimen are shown in $\mathrm{Figs} .4-6$. The specimens

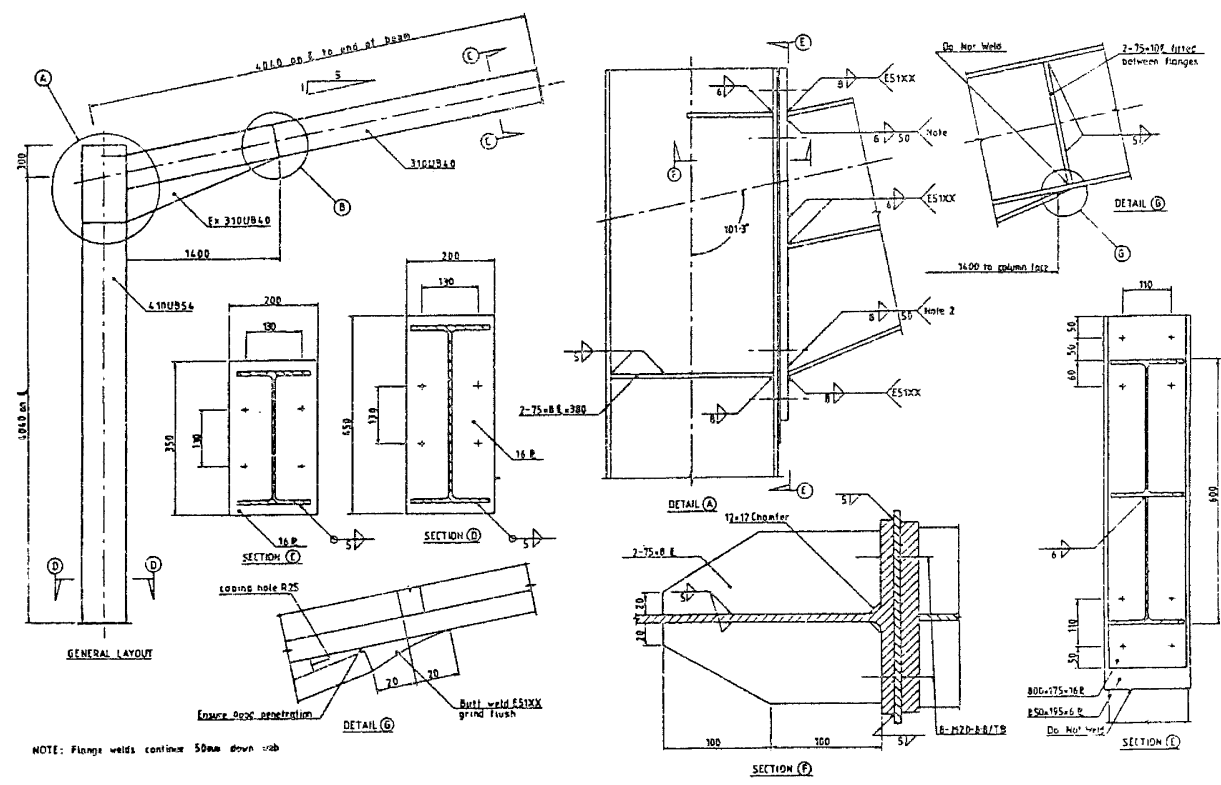

FIG. 3 - SPECIMEN THREE DETAILS

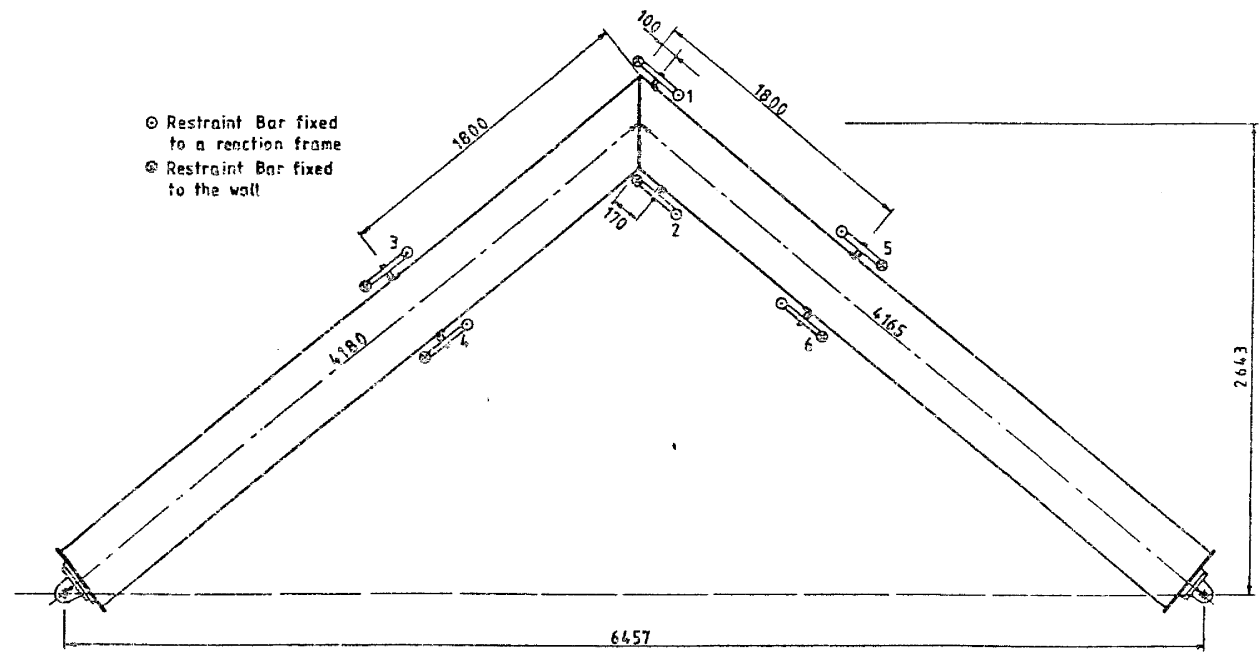

FIG. 4 - SPECIMEN ONE TEST LAAYOUT 


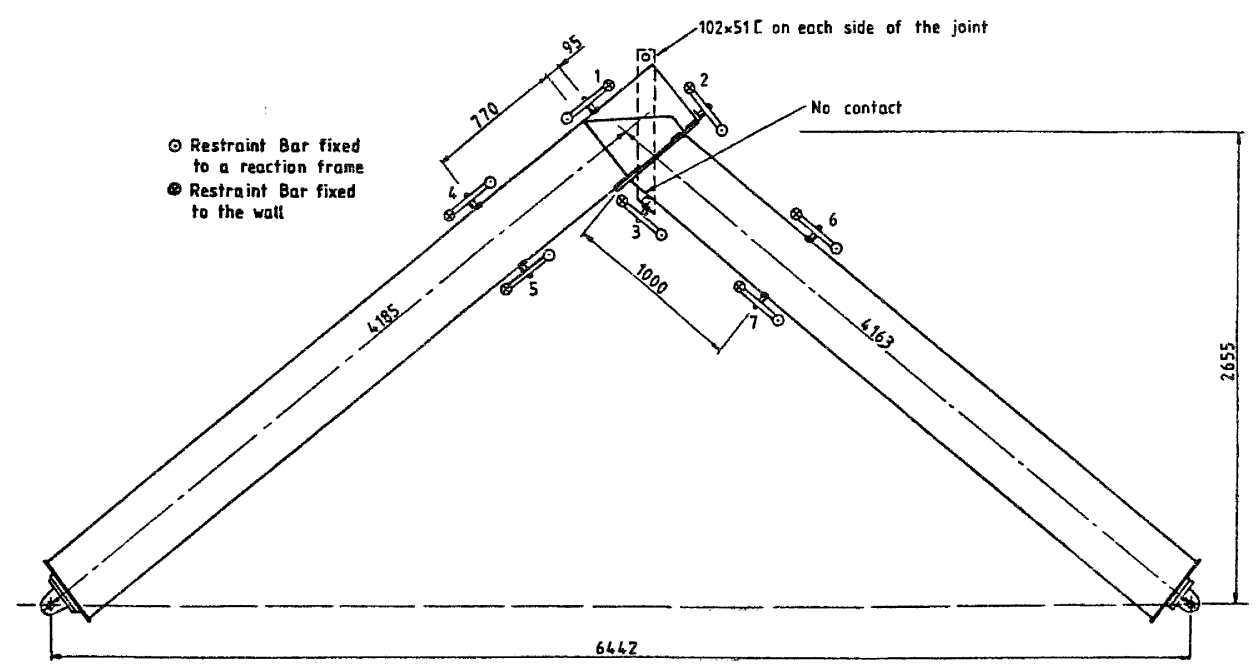

FIG. 5 - SPECIMEN TWO TEST LAYYOUT

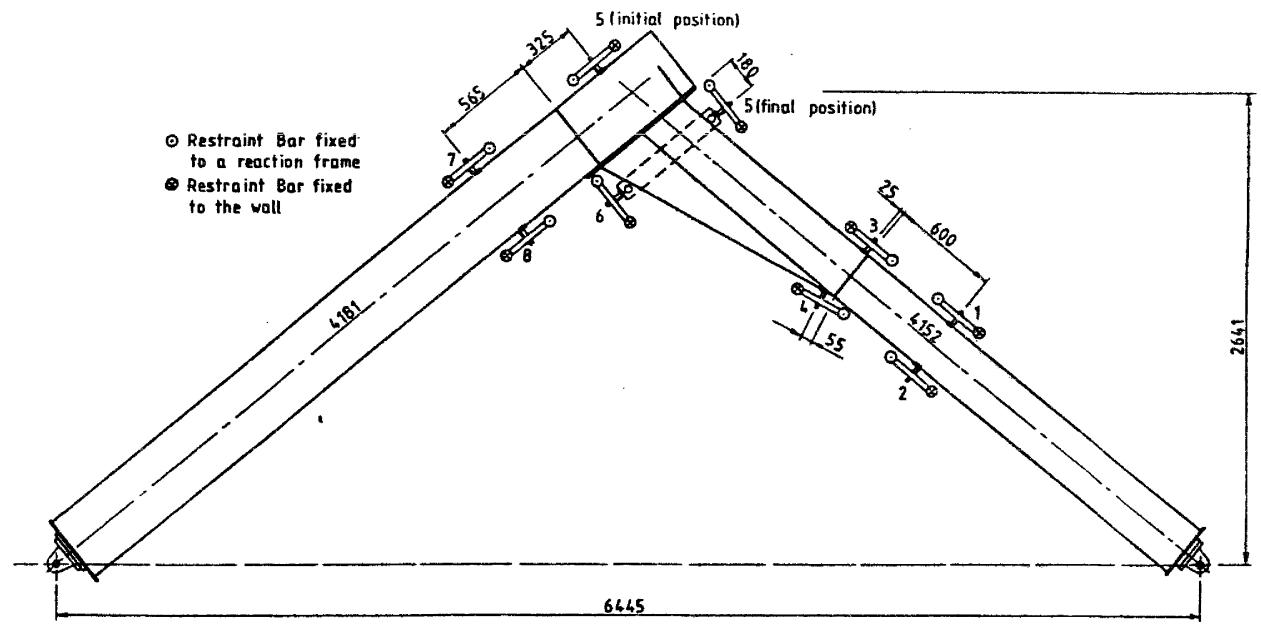

FIG. 6 - SPECIMEN THREE TEST LAYOUT

were set up vertically between a fixed hinge at the end of the column and a hydraulic jack at the beam end. The lateral restraints are a straight line mechanism which allows large deflections in the plane of the specimen with negligible lateral movement. The restraint pivots were attached to the member flanges using clamps or cleats welded to the connection where convenient. The clamps were found later to be unsuitable for use in plastic hinge regions. The restraint bars were instrumented and calibrated to enable the restraining forces to be measured.

Linear strain gauges were attached at various poistions along the beams and joint components and rosette strain gauges attached to the web panel areas to measure shear strains. Extensometers were used to measure joint deformations and plastic hinge rotations. All instrument readings were recorded at frequent intervals on a datalogger system.

A method developed by Surtees and Ibrahim (1980), where the average strain in rosette gauges fitted to bolt heads was calibrated against the force, was used to measure the bolt forces in specimens 2 and 3. When calibrating the bolts it was found that a reliable estimate of the maximum force to which a bolt has been subjected was given by the onset of non-linearity in the load versus strain plot for a subsequent load cycle. After the tests were completed the bolts were re-calibrated to determine the maximum loads reached and their ultimate strength. When tightening the bolts the load was monitored to determine when the proof load was reached. In all cases the load was reached with less than one 


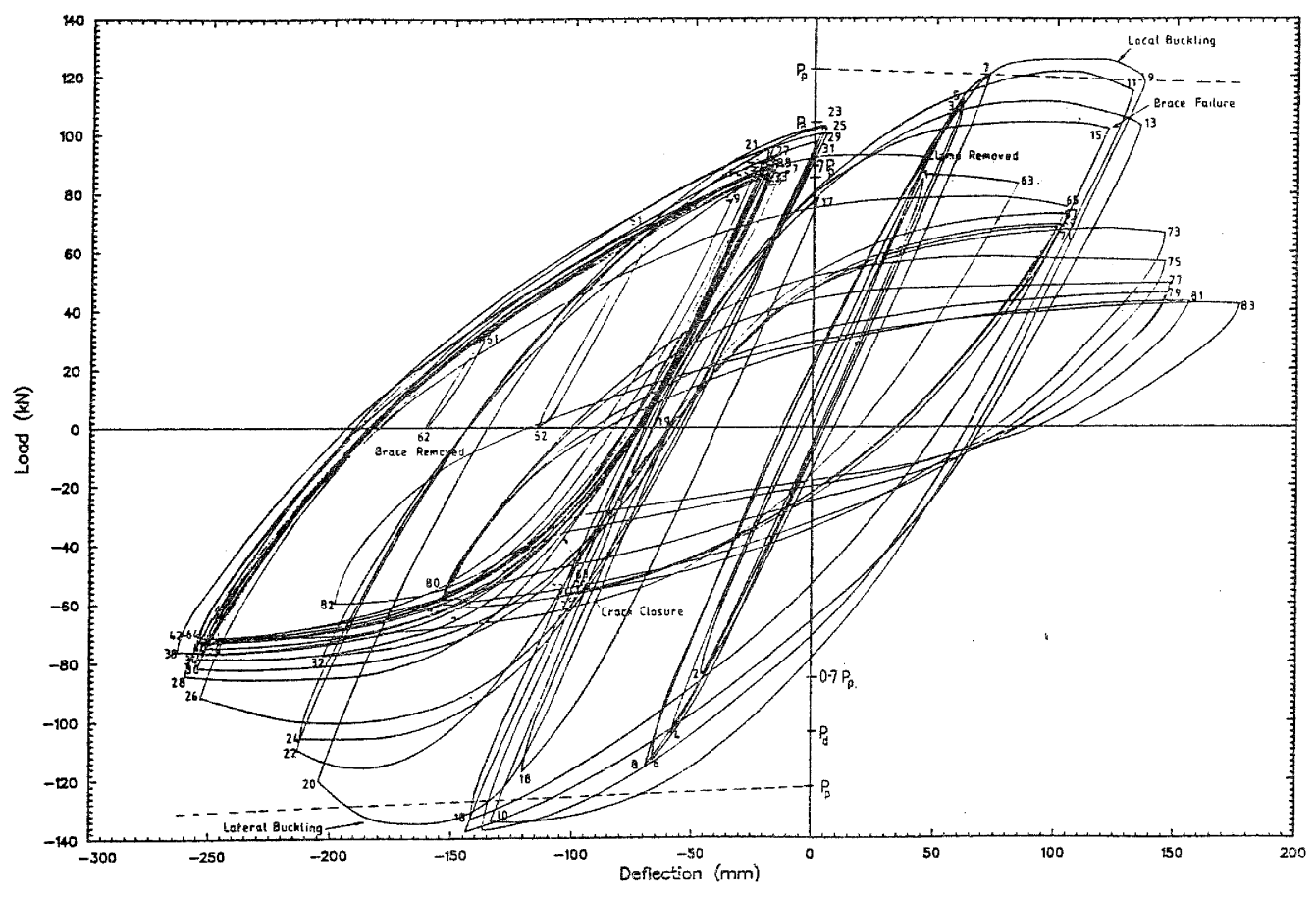

FIG. 7 - JACK LOAD VERSUS DEFLECTION, SPECIMEN ONE

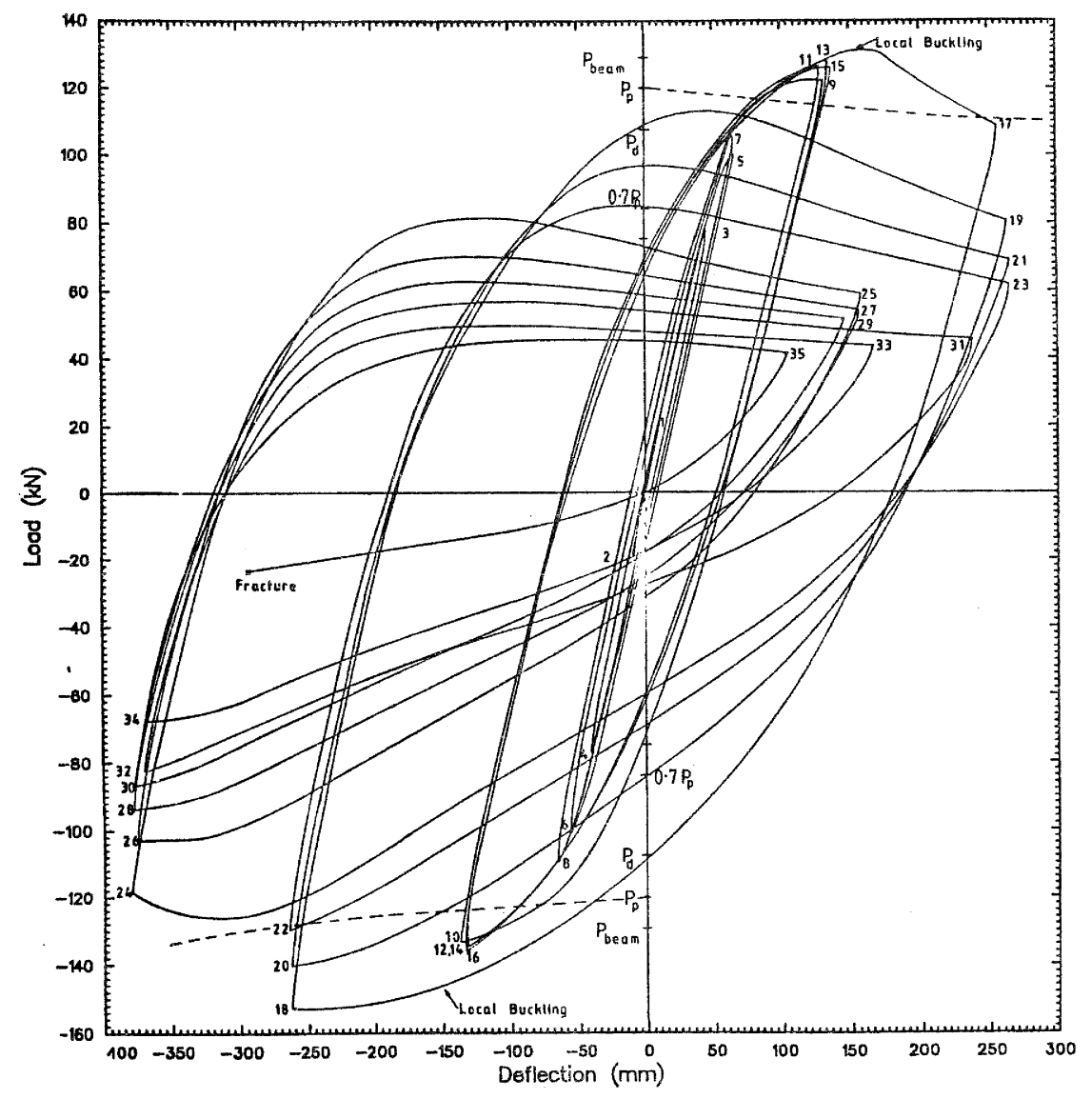

FIG. 8 - JACK LOAD VERSUS DEFLECTION, SPECIMEN TWO 
half turn from the 'snug tight' condition if this was assumed to be the load required to bring the plies into contact.

A typical load sequence comprised two or three cycles at a low load level; one cycle at $1 / 3,2 / 3$ and then the full predicted yield load; two cycles at ductility factor 1.0 and then further cycles at gradually increasing ductility factor until failure. The deflection at the predicted plastic moment of the weakest member was calculated using the measured stiffness of the specimen. In later cycles the closing displacements in tests one and two were limited to avoid serious damage to the lateral restraint components.

\section{RESULTS}

Plots of jack load versus deflection for the three tests axe shown in Figs. 7-9 and some of the numerical results are summarised in Table 1 . The numbers at the end of each curve segment indicate the excursion number and the dashed lines indicate the calculated collapse load for a rigidplastic mechanism. The loads at the design plastic moment and $70 \%$ of the calculated beam plastic moment are also shown. The commentary to NZS 4203 : 1976 suggests the use of a $30 \%$ reduction in the member strength as the failure criterion.

For comparison with the code limits on flange and web slenderness ratios (AS 1250-1981) the values using the measured yield stresses are indicated in Table 1. The flange ratios are equal to or exceed the allowable value (136). The web ratios all exceed the maximum value allowed by NZS 3404 : 1977 for plastic hinge regions $(800)$ when the measured web yield stress is used. The minor axis slenderness ratios for either the top or the bottom flange in compression are compared to the lower limit given in AS 1250 .

The maximum ductility factors given in Table 1 are calculated using the elastic deflection at the beam plastic moment. The maximum member ductility factors are calculated from the measured plastic hinge rotations but in some cases the members could be considered to have "failed" before reaching that ductility factor.

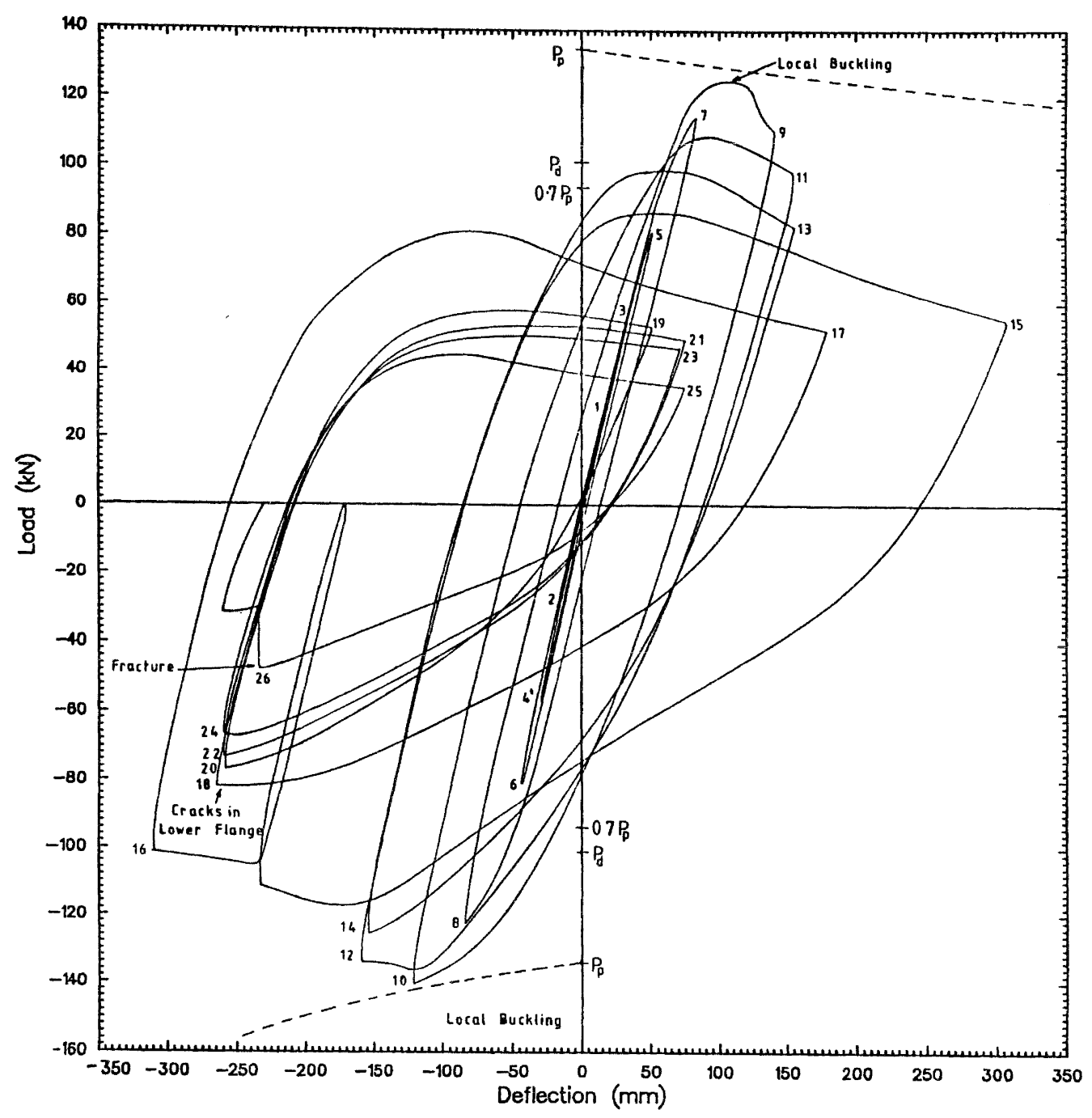

FIG. 9 - JACK LOAD VERSUS DEFLECTION, SPECIMEN THREE 


\begin{tabular}{|c|c|c|c|}
\hline Test Specimen Number & 1 & 2 & 3 \\
\hline $\begin{array}{l}\text { Beam section } \\
\text { Col umn Section }\end{array}$ & $\begin{array}{l}410 \cup B 54 \\
410 \cup B 54\end{array}$ & $\begin{array}{l}410 \text { J } B 54 \\
410 \text { J B54 }\end{array}$ & $\begin{array}{l}41 \text { ONB54 } \\
31 \text { OUB40 }\end{array}$ \\
\hline $\begin{array}{l}\text { Beam flange yield stress (MPa) } \\
\text { Beam web yield stress (MPa) } \\
\text { Col umn flange yield stress (MPa) } \\
\text { Col umn web yield stress (MPa) }\end{array}$ & $\begin{array}{l}301 \\
328 \\
301 \\
328\end{array}$ & $\begin{array}{l}293 \\
351 \\
274 \\
328\end{array}$ & $\begin{array}{l}303 \\
406 \\
309 \\
377\end{array}$ \\
\hline $\begin{array}{l}\text { Beam plastic moment: design, actual (kNm) } \\
\text { Column plastic moment: design, actual }(\mathrm{kNm}) \\
\text { Jack load for beam plastic moment ( } \mathrm{kN}) \\
\text { Jack defln. at beam plastic moment (mm) }\end{array}$ & $\begin{array}{l}273,322 \\
273,322 \\
122 \\
67.4\end{array}$ & $\begin{array}{l}273,323 \\
273,300 \\
129 \\
66.9\end{array}$ & $\begin{array}{l}162,216 \\
273,350 \\
135 \\
75.2\end{array}$ \\
\hline Beam flange slenderness, $b_{1} / T, b_{1} \sqrt{f_{y}} / T$ & $7.92,137$ & $7.97,136$ & $7.74,140$ \\
\hline Beam web slenderness, $d_{1} / t, d_{1} \sqrt{f_{y}} / t$ & $50.0,906$ & $49.4,926$ & $49.5,997$ \\
\hline $\begin{array}{l}\text { Max. permissible axial force }(\mathrm{KN}) \\
\text { Beam minor axis slenderness ratios } \mathrm{L} / \mathrm{r}_{\mathrm{y}} \\
\text { - lower flange } \\
\text { - upper flange }\end{array}$ & $\begin{array}{r}281 \\
39 \\
47\end{array}$ & $\begin{array}{l}261 \\
25 \\
23\end{array}$ & $\begin{array}{l}127 \\
16 \\
16\end{array}$ \\
\hline Lower limit for slenderness: $640 / \sqrt{f_{y}}$ & 37 & 37 & 37 \\
\hline $\begin{array}{l}\text { Max. +ve deflection (mm) } \\
\text { Max. - ve deflection (mm) } \\
\text { Max. +ve ductility factor } \\
\text { Max. - ve ductility factor }\end{array}$ & $\begin{array}{r}137 \\
-262 \\
2.0 \\
-3.9\end{array}$ & $\begin{array}{r}265 \\
-380 \\
4.0 \\
-5.7\end{array}$ & $\begin{array}{r}307 \\
-310 \\
4.1 \\
-4.1\end{array}$ \\
\hline $\begin{array}{l}\text { Max. +ve member ductility factor, beam } \\
\text { Max. - ve member ductil ity factor, beam } \\
\text { Max. + ve member ductility factor, column } \\
\text { Max. - ve member ductil ity factor, column }\end{array}$ & $\begin{array}{r}3.2 \\
-3.9 \\
1.4 \\
-2.4\end{array}$ & $\begin{array}{r}5.0 \\
-8.5 \\
1.9 \\
-3.5\end{array}$ & $\begin{array}{r}12.3 \\
-14.0 \\
- \\
-\end{array}$ \\
\hline $\begin{array}{l}\text { Max. +ve jack load }(\mathrm{kN}) \\
\text { Max. - ve jack load }(\mathrm{kN}) \\
\text { Max. + ve bend ing moment in beam }(\mathrm{kNm}) \\
\text { Max. - ve bend ing moment in beam }(\mathrm{kNm})\end{array}$ & $\begin{array}{r}126 \\
-138 \\
337 \\
-350\end{array}$ & $\begin{array}{r}132 \\
-153 \\
343 \\
-355\end{array}$ & $\begin{array}{r}126 \\
-140 \\
207 \\
-212\end{array}$ \\
\hline $\begin{array}{l}\text { Max. Iateral restraint force }(\mathrm{kN}) \\
\text { Min. ult. bolt force, } \max \text { bolt force }(\mathrm{kN})\end{array}$ & 26.5 & 282,330 & 196,200 \\
\hline
\end{tabular}

TABLE 1 - SUMMARY OF TEST RESULTS

The local buckling of the lower beam flange in specimen one was initiated by the twisting moment applied to the flange by the lateral restraint clamp during the first cycle to $D F=2$. At this point the force in the restraint was $8 \mathrm{kN}$ (about $1.4 \%$ of the flange force). In later cycles the local buckling became so severe that a bearing in the restraint assembly failed. In subsequent cycles the displacement in the closing direction was restricted to avoid further damage. The flange buckling was followed by large distortions in the web (Fig. 11) and a rapid increase in the maximum lateral restraint force. Lateral-torsional buckling of the upper flange began in the first cycle to
$\mathrm{DF}=-3$ accompanied by local buckling of the upper flange leading to a large reduction in load capacity.

Specimen two, which was braced to prevent lateral-torsional buckling, showed the best performance of all three specimens. Local buckling did not occur until the first cycle of $\mathrm{DF}= \pm 4$ when buckling started in both beam flanges accompanied by web buckling. After 4 cycles at this displacement the moment capacity for the closing direction had reduced to less than $70 \%$ of the plastic moment. The large local buckling deformations resulted in high forces in the lateral restraints - the peak force was $32 \mathrm{kN}$ or 


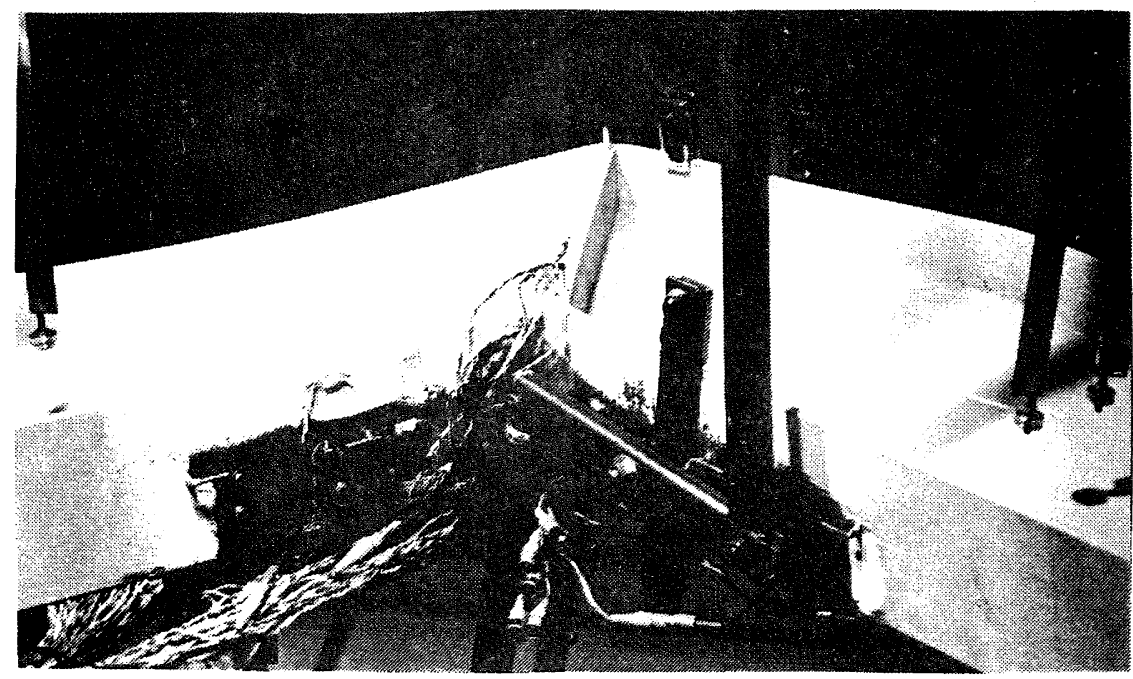

FIG. 10 - LATERAL-TORSIONAL BUCKLING IN SPECIMEN ONE

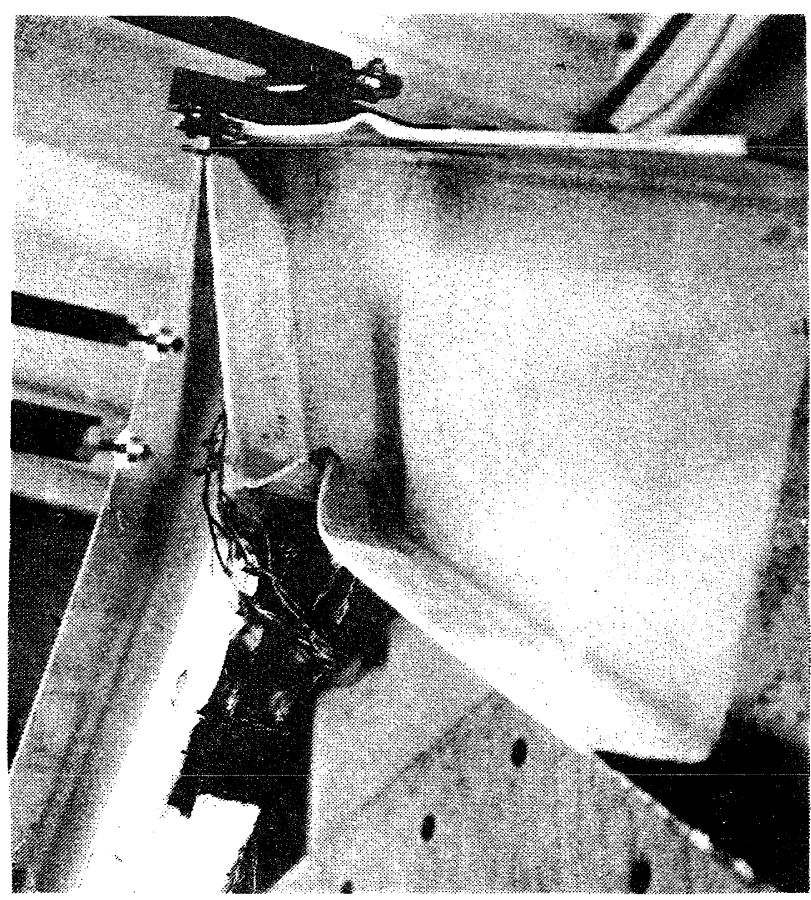

FIG. 11 - LOCAL BUCKLING IN SPECIMEN ONE SHOWN AT TEST COMPLETION

about 5.8 of the flange yield force which is more than twice the design ultimate load specified in AS $1250(2.5 \%)$.

In specimen three almost all of the inelastic deformation was concentrated in the beam at the end of the haunch so that large plastic hinge rotations were required at moderate ductility factors. The member ductility factor at an overall ductility factor of 2.0 was estimated to be 6.1 . Three cycles at this displacement level were completed before the moment capacity fell below $70 \%$ of the plastic moment. The calculated plastic moment may not be accurate since the yield stress measured at the centre of the web was quite high (406 MPa) and may not have been uniform over the web depth as assumed. The flange and web local buckling was particularly severe in this test and was reflected in the high lateral restraint forces $(29.4 \mathrm{kN}$ or $6.0 \%$ of the flange yield force).

The performance of all connection components in the three tests was adequate 


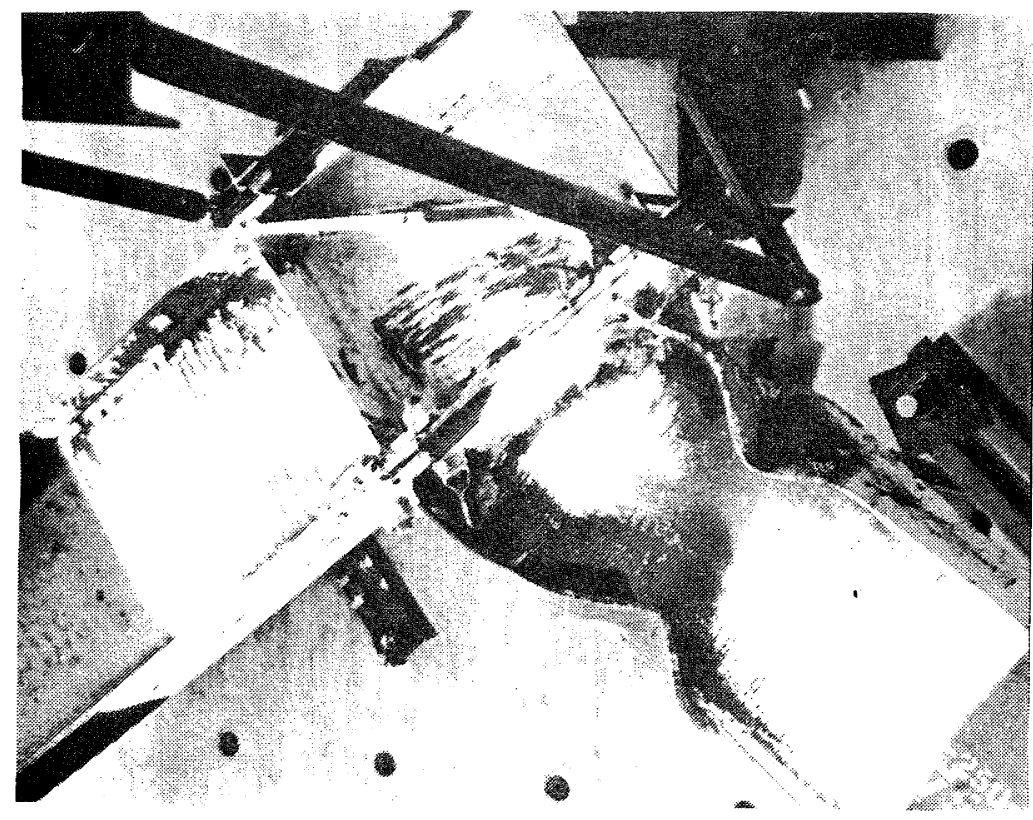

FIG. 12 - SPECIMEN TWO AFTER COMPLETION OF TEST

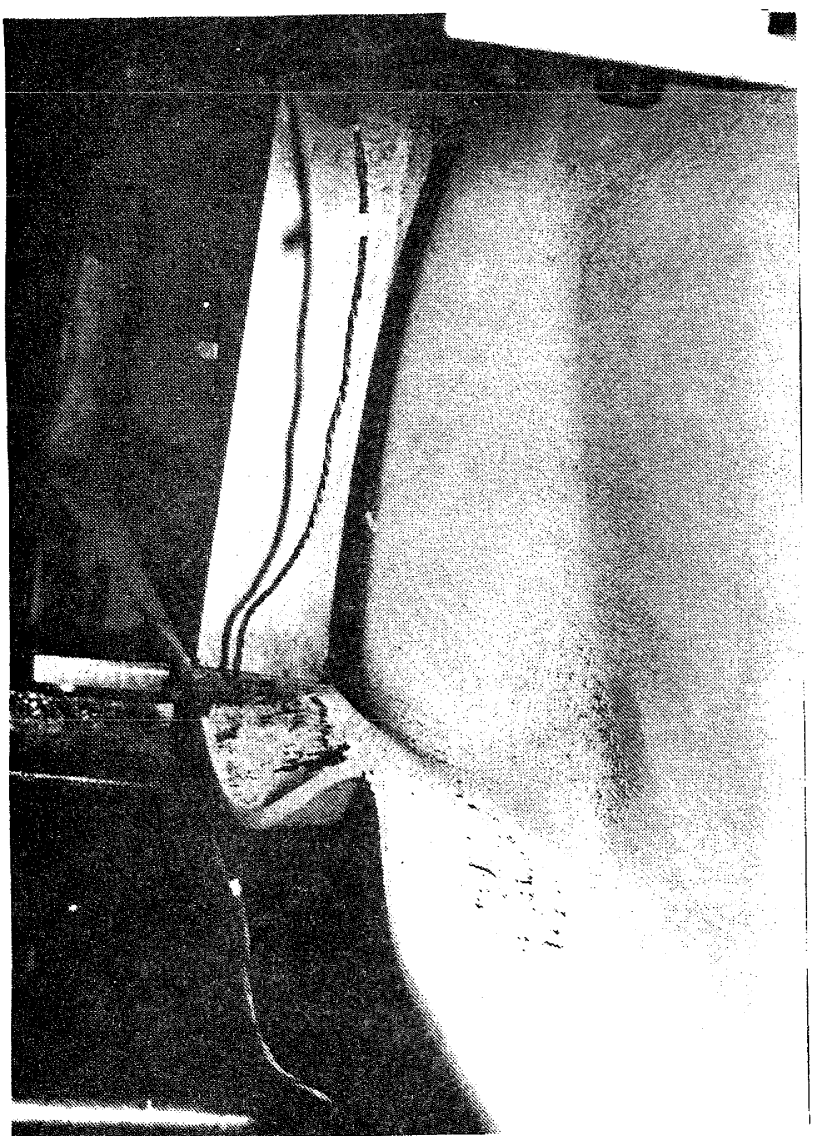

FIG. 13 - LOCAL BUCKLING AT END OF HAUNCH IN SPECIMEN THREE 
but it should be noted that the number of cycles at maximum load was limited by buckling in the beams. The maximum separation between end plate and columir flange in specimen three was $5 \mathrm{~mm}$ which should be considered to be at the tolerable limit for $a$ portal frame structure. In structures where deflection control is more importart, thicker end-plates should be used. In specimen two the forces in the bottom row of bolts at the lower flange connection exceeded the specified uitimate loads. Subsequent testing showed that the minimum ultimate strength of the bolts was $347 \mathrm{kN}$. The maximum prying forces in the bolts were estimated to be $28 \%$ of the force calculated by sharing the flange force equally between the 4 bolts (with 05 error margin). The method used to stiffen the column flanges against the bolt tension forces proved to be highly effective.

In all three tests the final failures were by fracture of the beam flanges at local buckles due to low cycle fatigue several cycles after cracks first appeared.

Out of the three specimens tested, only specimen two could be considered to have provided 'adequate ductility' which the commentary to NZS 4203 : 1976 suggests is 8 load reversals at a ductility factor of \pm 4 without the load capacity of any member being reduced by more than $30 \%$. Specimer. three would have had 'adequate ductility' if the beam was considered as an isolated member.

\section{CONCLUSIONS}

Under cyclic flexural loading local flange buckling can occur in members having flange slenderness ratios close to plastic design code limits at relatively low ductility factors. If web buckling also occurs then the local buckling is particularly severe and the load capacity of the member may be substantially reduced. The local buckling is more severe at the insice flange of a portal frame knee joint due to the extra compressive axial force.

Lateral-torsional buckling may also occur after a number of cycles in members where the lateral restraint spacing satisfies the code rules. The distortions and twisting of the cross section caused by local buckling will probably result in earlier initiation of lateral-torsional buckling. The high lateral restraint forces observed in the tests on closely braced specimens where severe local buckling occurred confirms the strong tendency for lateraltorsional buckling to occur in such members.

Increased ductility could be achieved by using stockier members in plastic hinge zones or by reducing the lateral restraint spacing and designing the restraints to withstand the higher forces. The test results suggest that lateral restraints may be required to withstand up to $5 \%$ of the flange squash load if severe local buckling occ.rs. This figure may be compared to the $4 \%$ of the flange force recommended by Morris and Randall (1979) for plastic design. If stockier members are used the local buckling would be less severe and the lateral rest- raint forces would be less but the possibility of premature lateral-torsional buckling remains. Tests by plugge and Walpole (1983) show that high levels of ductility can be achieved using members with flange slenderness ratios less than those for the tests reported in this paper.

The local buckling which occurred in specimen one show that lateral restraint cleats should not be located in plastic hinge regions unless the flange is suitably stiffened or the cleat is restrainad against torsion.

High material yield stresses may have been partly responsible for the earlier than anticipateã local flange and web buckling since the critical stresses could have been reached at lower deformation levels. However in a real structure subjected to earthquake loading, overstrength members will, in general, lead to decreased ductility demand so the significance of the higher yield stresses may be reduced.

Portal. frames with haunched beams should be designed so that the plastic hinge forms at the top of the column to avoid the high ductilicy demand in the beam at the end of the haunch. It may be observed that local buckling did not occur in the column of specimen two which was in theory weaker than the beam. It is possible that the end plate and the flange reinforcement plate prevented local buckling.

\section{ACKNOWLEDGEMENTS}

The research on which this paper is based was undertaker in the Department of Civil Engineering, University of Auckland, under the supervision of Dr. J.W. Butterworth whose guidance and assistance is gratefully acknowledged.

The author would like to thank the New Zealand Heavy Engineering Research Association for their generous financial support.

\section{REFERENCES}

Beamish, M.J. 1984. Seismic Behaviour of Steel Portal Frame Knee Joints. University of Auckland, School of Engineering, Department of Civil Engineering, Report No. 348.

Johnstone, N.D. and Waipole, W.R. 1981. Bolted End-Plate Connections Under Earthquake Type Loading. Research Report 81-7, Department of Civil Engineering, University of Canterbury.

Mann, A.P. and Morris, L.J. 1979. Limit Design of Extended End-Plate Connections. Journal of the Structural Division, ASCE 105 (ST3) 511-526.

Matsui, C. amd Yoshizumi, T. 1980. Influence of Local and Lateral Buckling of Inelastic Behaviour of Steel Frames. Proceedings of the 7 th World Conference on Earthquake Engineering, Istanbul, V7 321-324.

Morris, L.J. 1981. A Commentary on Portal 
Frame Design. The Structural Engineer 59A (12) 394-404.

Morris, L.J. and Randall, A.I. 1979. Plastic Design. Constrado.

Plugge, H.B. and Walpole, iN.R. 1983. The Tenacity of Bolted Beam End-Plate to Column Connections Under Simulated Seismic Loading. Research Report 83-2, Department of Civii Engineering, University of Canterbury.

Popov, E.P. 1973. Experiments with Steel Members and their Connections Under Repeated Loads. Proc. Symp. on the Resistance and Ultimate Deformability of Structures acted on by Well Defined Repeated Loads, IABSE, Lisbon, 143-149.

Standards Association of Australia, 1981. SAA Steel Structures Code. AS 1250. Sydney.

Standards Association of New Zealand. 1976. Code for Practice for General structural Design and Design Loadings for Buildings. NZS 4203. Wellington.

Standards Association of New Zealand, 1977. Code for Design of Steel Structures. NZS 3404 . Wellington.

Surtees, J.O. and Ibrahim, M.E. 1980. Bolt Tension Measurement from Head strain Data. Journal of the Structural Division, ASCE 106(ST2) 477-490.

Surtees, J.O. and Mann, A.P. 1970. End Plate Connections in Plastically Designed Structures. Conference on Joints in Structures. University of Sheffield, paper A5.

Vann, W.P., Thompson, L.E., Whalley, L.E. and Ozier, L.D. 1973. Cyclic Behaviour of Rolled Steel Members. Proceedings of the 5 th World Conference on Earthquake Engineering, Rome, 11871193.

Whittaker, D. and Walpole, W.R., 1982. Bolted End-Plate Connections for Seismically Designed Steel Frames. Research Report 82-11, Department of Civil Engineering, University of Canterbury.

Zoetemeijer, P. 1981. Semi-Rigid Beam-to-Beam Column Connections with Stiffened Column Flanges and Flush-End Plates. Conference on Joints in Structural Steelwork, Teeside Polytechnic, England, $2.99-2.118$.

\section{NOTATION AND TERMINOLOGY}

$B=$ flange wiath $T=$ flange thickness

$\mathrm{b}_{1}=$ flange outstand $(\mathrm{B}-\mathrm{t}) / 2 \quad \mathrm{t}$ = web thickness

$\mathrm{D}=$ overall nember depth

$\mathrm{d}_{1}=$ clear web depth between flanges $\mathrm{D}-2 \mathrm{~T}$

$f_{y}=y i e l d$ stress

$L=$ effective length for lateral buckling

$M_{p}=$ plastic moment of resistance

$\mathrm{P}_{\mathrm{a}}=$ value of $\mathrm{P}_{\mathrm{p}}$ calculated using specified member properties

$\mathrm{P}_{\mathrm{p}}=$ jack load when plastic moment in weakest member is reached

$r_{y}=$ radius of gyration about minor axis

Flange slenderness: defined by the ratio $\mathrm{b}_{1} / \mathrm{T}$

Web slenderness: defined by the ratio $d_{1} / t$

Minor axis slenderness: defined by the ratio $\mathrm{L} / \mathrm{r}_{\mathrm{y}}$

Ductility Factor (DF): ratio of the maximum jack deflection to the elastic jack deflection when the beam plastic moment is reached

Member Ductility Factor: ratio of the maximum transverse deflection at the end of the member to the transverse deflection at the member plastic moment 